\title{
Physicochemical properties of a flowing stream in Jabi, Abuja, Nigeria
}

\author{
Solomon, R. J.* and Kehinde, O. A. \\ Department of Biological Sciences, Faculty of Science, University of Abuja, Abuja, Nigeria. \\ ${ }^{*}$ Corresponding author E-mail: johnsol2004@yahoo.com
}

Copyright @ 2017 Solomon and Kehinde. This article remains permanently open access under the terms of the Creative Commons Attribution License $\underline{4.0}$, which permits unrestricted use, distribution, and reproduction in any medium, provided the original work is properly cited.

Received 5th April, 2017; Accepted 28th April, 2017

\begin{abstract}
The physicochemical qualities of flowing stream located in Jabi, Abuja, Nigeria was assessed over the duration of 3 months. Parameters measured include $\mathrm{pH}$, temperature, electrical conductivity, turbidity, biological oxygen demand (BOD), dissolved oxygen, chemical oxygen demand, nitrate, sulphate, acidity, alkalinity, and carbon levels and these were simultaneously monitored in the flowing stream using standard methods. Unacceptably, high levels of the assayed parameters were observed in Nitrate (1.39 to $1.44 \mathrm{mg} / \mathrm{L})$, while dissolved oxygen $(3.2$ to $11.6 \mathrm{mg} / \mathrm{L})$ and turbidity (8.6 to 9.1 NTU) were totally outside the compliance levels of the Federal Environmental Protection Agency (FEPA) Guidelines and World Health Organization (WHO) tolerance limits for domestic uses. The study has revealed that there was an adverse impact on the physiochemical characteristics of the flowing stream as a result of discharge of inadequately treated waste products from surrounding communities. This poses a health risk to several rural communities which rely on flowing stream primarily as their sources of domestic water and also harmful to aquatic life. There is need for the intervention of appropriate regulatory agencies to ensure flowing stream is hygienic for consumption and aquatic life through proper channelling.
\end{abstract}

Kew words: Biological oxygen demand, chemical oxygen demand, Chloride, Fluoride, dissolve oxygen, Jabi, Magnesium, Nitrate, $\mathrm{pH}$, physicochemical, temperature, total hardness, turbidity.

\section{INTRODUCTION}

Water is the most abundant compound on the Earth surface, covering about 70 percent of the planet. In nature, water exists in liquid, solid and gaseous states. It is in dynamic equilibrium between the liquid and gas state at standard temperature and pressure. At room temperature, it is a tasteless and odorless liquid, nearly colorless with a hint of blue. Many substances dissolves in water and it is commonly referred to as the universal solvent. Because of this, water in nature and in use is rarely pure. However, there are also many compounds that are essentially, if not completely, insoluble in water. Water is the only common substance found naturally in all three common states of matter and it is essential for all life on earth. Water makes of 55 percent to 78percent of the human body.

Fresh water has become a scarce commodity due to over exploitation and pollution (Ghose and Basu 1968,
Gupta and Shukle, 2006; Patil and Tijare, 2001). Pollution is caused when a change in physical, chemical or biological condition in the environment harmfully affects quality of human life, animals and plant (Thompson et al., 2004; Okoye et al., 2002). Industrial, sewage and municipal are been continuously added to water bodies hence affects the physiochemical quality of water making them unfit for use on livestock and other organisms (Dwivedi and Pandey, 2002).

Uncontrolled domestic water discharged into pond has resulted in eutrophication of ponds as evidence by substantial algal bloom, dissolved oxygen depletion in the subsurface water leads to the death of large fish and other oxygen dependent organisms (Rast and Thornton, 1996; WRC, 2000).

Effluent discharged into environment with enhanced concentration of nutrient, sediments and toxic substances 
may have a serious negative impact in quality of the receiving water body when discharged untreated or partially treated (Forenshell, 2001; Schulz and Howe, 2003). Water pollution by effluent has become a question of considerable pubic and scientific concern in the light of the evidence of their extreme toxicity to human health and to biological ecosystem (Katsuro et al., 2004). The occurrence of heavy metals in industrial and municipal sewage effluence constitute a major source of heavy metal entering aquatic media. Hence, there should be regular assessment of this sewage effluence to ensure that adequate measures are taken to reduce pollution level to the minimal.

Worldwide, water bodies are primarily means for disposal of waste, especially the effluence from industrial, municipal sewage and agricultural practices that are closed to them. This effluence can alter the physical, chemical and biological nature of receiving water body (Sandoyin, 1991). The initial effect of waste is to degrade physical quality of the water. Later biological degradation becomes evident in terms of number, variety and organization of the living organisms in the water (Gray, 1989). Often, the water bodies readily assimilate waste materials they receive without significant deterioration of some quality criteria; the extent of this referred to as its assimilative capacity (Fair, 1971). However the water quality is deteriorating day by day due to anthropogenic impute of dissolve nutrient and organic matter and industrial effluent which is built up on its bank. So, it is of vital importance to monitor and simulate the water quality parameters to ascertain whether the water is still suitable for various uses. Water contaminated by effluent from various sources is associated with heavy disease burden (Okoh, 2007) and this could influence the current shorter life expectancy in the developing countries compared with developed nations (WHO, 2002).

Due to population explosion and moderate rapid urbanization, people rely heavily on water sources of doubtful quality in the absence of better alternatives, or due to economic and technological constraint to adequately treat the available water before use (Aina and Adedipe, 1996, Calamari and Naeve 1994). The scarcity of clean water and the pollution of fresh water have therefore led to a situation in which one-fifth of the urban dwellers in developing countries and three-quarter of their rural dwelling population do not have access to reasonably safe water supplies (Lloyd and Helmer, 1992)

Effluent are composed mainly of either organic, inorganic matter or both and toxic substances depending on its source. Inorganic matter in effluent are formulated using various chemical containing nitrogen, phosphorous and potassium. These elements especially phosphorous stimulate the growth of microscopic plant while nitrogen promotes overgrowth of aquatic vegetation which degrades water quality. Potassium promotes productivity of aquatic animals such as fish (Wurts 2000). Organic matter in effluent are formulated using various chemicals containing carbon, nitrogen and phosphorus. Organic matter promotes the growth of zooplanktons as well as macro benthic invertebrates (Adigun, 2005). Organic matter also stimulates the growth of decomposers such as bacteria and fungi.

Bacteria and fungi are very critical to the breakdown of the toxic components of the effluent. It has been observed that dissolved oxygen in water is required during the decaying of the organic matter, which may lead to the depletion of oxygen in the water body and cause harmful substance to accumulate (Watson and Cichra, 2006). Organic matter contains high concentration of ammonia, which may occur as bubbles attached to the block solid materials known as benthic deposits.

Contamination of the environment by effluent viewed as an international problem because of the effect on the ecosystem in most countries. In Nigeria, the situation is no better by the activities of most industries and populace towards waste disposal and management which usually leads to the increasing level of pollution of the environment. Sewage discharge is a major component of water pollution which is compounded in areas where waste water treatments are inefficient. Such is the case of the Jabi stream which is a running stream.

This receiving stream serves as a source of water to some communities downstream which are used for a variety of purposes like irrigation, drinking, aquatic life and other domestic uses without prior treatment. The present study on the physiochemical parameters is significant in that some of these parameters may prove lethal to aquatic flora, fauna and ultimately humans who are usually at the top of the food chain. The receiving stream serves as a convenient means of cleaning the highly loaded sewage and carries waste away from its discharge point. The need to know the quality of the water from the receiving stream has informed this study. The study will also provide information on the performance efficiency of the sewage lagoon.

\section{MATERIALS AND METHOD}

Sampling point were the river is situated is at Utako with Latitude $008^{0} 7.44 \mathrm{E}$, Longitude $005^{\circ} 9.08 \mathrm{~N}$ with elevation $285 \mathrm{~m}$ above sea level using global position system (GPS) to determine the coordinate and elevation.

\section{Sampling}

Samples were collected in $250 \mathrm{ml}$ glass bottle for dissolved oxygen and biological oxygen demand. Also samples were collected in plastic bottle for other physiological parameters, pre cleaned by washing with 
non-ionic detergents and rinsed in tap water. Before sampling, the bottles were rinsed three times with sample water before being filled with the sample. The actual samplings were done midstream by dipping each sample bottle at approximately 20 to $30 \mathrm{~cm}$ below the water surface, projecting the mouth of the container against the flow direction. The samples were then transported in cooler boxes.

\section{Physicochemical analysis}

All field meters and equipment were checked and calibrated according to the manufacturer's specifications. $\mathrm{pH}$, temperature, electrical conductivity, transparency, dissolved oxygen, organic matter, organic carbon and chemical oxygen demand (COD) of the samples were determined by titration while biological oxygen demand (BOD) was determined five days after sampling. Samples were kept in BOD bottles in cool cupboard. Acidity and alkalinity were determined in the laboratory on the day of sampling. The concentrations of sulphate and nitrate were determined in the laboratory by using standard colorimeter.

\section{Statistical analysis}

The obtained data were subjected to descriptive statistical analysis (95\% confidence limit). The computation were achieved with the use of statistical package for social science (SPSS) to determine the mean, standard deviation, threshold and coefficient of variation and range values.

\section{RESULTS AND DISCUSSION}

The water samples were collected for over a period of three months. One sample was collected from each sampling point. The results were presented in Tables 1, 2 and 3 . The physiochemical characteristic of water is important determinant of aquatic system. Their characteristic is greatly influenced by climate, vegetation and general composition of water.

\section{pH}

Water in a pure state has a neutral $\mathrm{pH}$. As a result, water is neither acidic nor basic. The $\mathrm{pH}$ values vary significantly $(p>0.05)$ in the water samples collected (from Jabi water flow) at month interval and ranged from 7.25 to7.50. Generally, the obtained $\mathrm{pH}$ values fall within the World Health Organization standard of 7.0 to 8.5 and the water quality ranges 6.5 to 8.5 for drinking water and meant for full contact recreation (DWAF, 1996; WHO, 1984; 1989). The European Union also set pH protection limits of 6.0 to 9.0 for fisheries and aquatic life (Chapman, 1996).

\section{Temperature}

The temperature profile of the flowing stream at Jabi varies significantly $(P>0.05)$ and ranged 19 to $23^{\circ} \mathrm{C} .25^{\circ} \mathrm{C}$ is the recommended limit for no risk according to the FEPA water quality guidelines for domestics use (DWAF, 1995) while $40^{\circ} \mathrm{C}$ is recommended limit according to WHO. Based on these guidelines, the temperature of the stream did not pose any threat to the homeostatic balance of the receiving water bodies, in conformity with the report of Jaji et al. 2007.

\section{Turbidity}

The turbidity profile varies significantly $(p>0.05)$ amongst the water samples collected from the water body and ranged from 8.62 to 9.11 NTU. The turbidity values obtained from the sampling points was higher than WHO standard of 5 NTU (WHO, 2004). None of the sample collected met the requirement of FEPA guidelines of 0 to 1 NTU for turbidities in water for domestic use (DWAF, 1998). These values are grossly exceeded in the water sample and disqualify the receiving water body for direct domestic use. Also the excessive turbidity in water can cause problem with water purification processes such as flocculation and filtration, which may increase treatment cost (DWAF, 1998). High turbid waters are often associated with the possibility of microbiological contamination, as high turbidity makes it difficult to disinfect water properly (DWAF, 1998).

\section{Dissolve Oxygen}

The dissolved oxygen profile through the period varied significantly ( $p>0.05)$ and ranged from 3.2 to $11.6 \mathrm{mg} / \mathrm{l}$ .Dissolved oxygen is an important factor used for water quality control. The effect of waste discharge on a surface water is largely determined by the oxygen balance of the system and its presence is essential in maintaining biological life within a system (DFID, 1999). Dissolved oxygen concentrations in unpolluted water normally range between 8 and $10 \mathrm{mg} / \mathrm{l}$ and concentration below $5 \mathrm{mg} / \mathrm{L}$ adversely affect aquatic life (DFID, 1999; Rao, 2005). Dissolve oxygen for standard water for drinking purpose is $6 \mathrm{mg} / \mathrm{L}$ whereas for sustaining fish and aquatic life is 4 to $5 \mathrm{mg} / \mathrm{L}$ (Rao, 2005). The dissolve oxygen value from this study fell short of the recommended standard (3.2 to $11.6 \mathrm{mg} / \mathrm{l})$. For water quality variable such as dissolved oxygen, water quality criteria are set at the minimum acceptable concentration to ensure the maintenance of biological function. 
Table 1. Physicochemical properties of the flowing stream in Jabi.

\begin{tabular}{llccc}
\hline Parameter & Unit & Jun 2014 & Jul 2014 & Aug 2014 \\
\hline DO & $\mathrm{Mg} / \mathrm{l}$ & 3.2 & 8.4 & 11.6 \\
BOD & $\mathrm{Mg} / \mathrm{l}$ & 1.6 & 0.8 & 6.0 \\
Temperature & $\mathrm{Oc}$ & 23 & 19 & 23 \\
Conductivity & $\mathrm{Us} / \mathrm{cm}$ & 289 & 284 & 295 \\
TDS & $\mathrm{Ppm}$ & 142 & 141 & 146 \\
$\mathrm{pH}$ & ---- & 7.45 & 7.25 & 7.50 \\
Total hardness & $\mathrm{Mg} / \mathrm{l}$ & 257 & 260 & 262 \\
Calcium hardness & $\mathrm{Mg} / \mathrm{l}$ & 115 & 113 & 110 \\
Magnesiun hardness & $\mathrm{Mg} / \mathrm{l}$ & 155 & 157 & 152 \\
Turbidity & $\mathrm{Mg} / \mathrm{l}$ & 8.92 & 9.11 & 8.62 \\
Chloride & $\mathrm{Mg} / \mathrm{l}$ & 43.4 & 44.3 & 48.7 \\
Alkalinity & $\mathrm{Mg} / \mathrm{l}$ & 110 & 118 & 113 \\
Iron & $\mathrm{Mg} / \mathrm{l}$ & 0.56 & 0.59 & 0.6 \\
Flouride & $\mathrm{Mg} / \mathrm{l}$ & 0.3 & 0.2 & 0.2 \\
Sodium & $\mathrm{Mg} / \mathrm{l}$ & 24.7 & 22.4 & 26.6 \\
Phosphate & $\mathrm{Mg} / \mathrm{l}$ & 0.87 & 0.89 & 0.91 \\
Sulphate & $\mathrm{Mg} / \mathrm{l}$ & 15.7 & 16.2 & 15.7 \\
COD & $\mathrm{Mg} / \mathrm{l}$ & 2.0 & 4.0 & 4.0 \\
\hline
\end{tabular}

DO, Dissolve oxygen, BOD, Biological oxygen demand, COD, Chemical oxygen demand and TDS,Total dissolve solid.

Table 2. Summary of basic statistics for flowing stream in Jabi.

\begin{tabular}{lccccc}
\hline $\begin{array}{l}\text { Physsiochemical } \\
\text { parameter }\end{array}$ & Range & Mean & $\begin{array}{c}\text { Standard } \\
\text { deviation }\end{array}$ & $\begin{array}{c}\text { Threshold } \\
\mathbf{X}+\mathbf{2 S}\end{array}$ & $\begin{array}{c}\text { Coefficient } \\
\text { of Variation }\end{array}$ \\
\hline DO $(\mathrm{mg} / \mathrm{L})$ & $3.2-11.6$ & 7.73 & 4.24 & 16.2 & 5.49 \\
BOD $(\mathrm{mg} / \mathrm{L})$ & $0.8-6.0$ & 2.80 & 2.80 & 8.4 & 1.00 \\
Temperature & $19-23$ & 21.7 & 2.31 & 26.3 & 1.06 \\
Conductivity & $284-295$ & 289 & 5.51 & 300 & 1.91 \\
TDS & $141-146$ & 143 & 2.65 & 148 & 1.85 \\
PH & $7.25-7.50$ & 7.4 & 0.13 & 7.66 & 1.76 \\
Total hardness & $257-260$ & 260 & 2.52 & 265 & 9.69 \\
Calcium & $110-115$ & 113 & 2.52 & 118 & 2.23 \\
Magnesium & $152-157$ & 155 & 2.52 & 160 & 1.63 \\
Turbidity & $8.62-9.11$ & 8.88 & 0.25 & 9.38 & 2.82 \\
Chloride & $43.4-48.7$ & 45.5 & 2.84 & 129 & 6.24 \\
Alkalinity & $110-118$ & 114 & 4.04 & 122 & 3.54 \\
Iron & $0.56-0.6$ & 0.58 & 0.02 & 0.62 & 3.45 \\
Fluoride & $0.2-0.3$ & 0.23 & 0.06 & 0.35 & 2.61 \\
Nitrate & $1.39-1.44$ & 1.43 & 0.02 & 1.47 & 1.39 \\
Sodium & $22.4-26.3$ & 24.5 & 1.06 & 26.6 & 0.08 \\
Phosphate & $0.87-091$ & 0.89 & 0.02 & 0.93 & 2.25 \\
Sulphate & $15.7-16.2$ & 15.9 & 0.29 & 16.5 & 1.82 \\
COD & $2.0-4.0$ & 3.33 & 1.15 & 5.63 & 3.45 \\
\hline
\end{tabular}

DO, Dissolve oxygen, BOD, Biological oxygen demand, COD, Chemical oxygen demand.

\section{Biological/chemical oxygen demand}

Both the BOD and COD test are measure of the relative oxygen - depletion effect of a waste contaminant. Both have been widely adopted as measure of pollution effect. The BOD test measures the oxygen demand of biodegra- 
Table 3. The mean values of physiochemical parameter of flowing stream in Jabi compare with standard limit.

\begin{tabular}{lccc}
\hline Parameter & Stream & FEPA & WHO \\
\hline DO mg/L & 7.73 & NOT $<2$ & 6 \\
BOD mg/L & 2.80 & 10 & 50 \\
Temperature & 21.7 & 26 & 40 \\
Conductivity & 289 & 70 & 5 \\
Turbidity & 8.88 & $<1$ & 5 \\
Alkalinity & 114 & $\mathrm{ND}$ & 250 \\
$\mathrm{pH}$ & 7.4 & $6-9$ & $7.0-8.5$ \\
Nitrate & 1.43 & 20 & $<45$ \\
COD mg/L & 3.33 & 80 & 1000 \\
Chloride & 45.5 & 240 & 250 \\
Fluoride & 0.23 & 1.2 & 1.5 \\
TDS mg/L & 260 & 148 & 159 \\
\hline
\end{tabular}

DO, Dissolve oxygen, BOD, Biological oxygen demand, COD, Chemical oxygen demand, FEPA, Federal environmental protection agency, ND,Not determined, and WHO, World Health Organization.

dable pollutants whereas the COD test measures the oxygen demand of oxidizable pollutants. The COD is a determinant of the level organic matter and carbon.

The chemical oxygen demand (COD) of the water sample generally varied from 2.0 to $4.0 \mathrm{mg} / \mathrm{L}$. At the month of July and August there was increase in the rate of COD. These could be due domestic activities and industrial activity which had a negative impact on the quality of fresh water and subsequently cause harm to aquatic animals (Morrison et al., 2001). The biological oxygen demand varies significantly from the water sample collected $(0.8$ to $6.0 \mathrm{mg} / \mathrm{L})$ (Table 1$)$. When this present result was compared with result of $C O D$ and BOD of the treated water bodies from developed countries, it was observed that the concentration of COD and BOD differ as reported by UNEP (1993) (Table 3). These results disqualify the use of the water for both domestics and drinking purpose (Fatoki et al., 2003).

\section{Nitrate}

The most highly oxidized form of nitrogen compounds is commonly present in surface and ground water because it is the end product of aerobic decomposition of organic nitrogenous matter. Unpolluted natural water usually contains only minute amounts of nitrate (Jaji et al., 2007). In this study, the nitrate $(\mathrm{N})$ concentrations ranged between 1.39 to $1.44 \mathrm{mg} / \mathrm{L}$ (Table 2) which vary significantly $(p>0.05)$. It is important to note that nitrate level in the water body could be a source of eutrophication as the obtained values exceeded the recommended limit for FEPA.

\section{Total hardness}

The total hardness of the sample collected varies significantly $(p>0.05)$. The total hardness values obtained from samples varied from 257 to 262 (Tables 1 and 2). The results obtained were higher than that of WHO standard for drinking water. The standard for the total hardness for drinking water by the WHO is $150 \mathrm{mg} / \mathrm{L}$ (WHO, 2004).

\section{Chloride}

The total chloride of the water samples obtained varies significantly $(p>0.05)$. The values for the total chloride obtained were 43.4 to 48.7 which was less than the WHO standards for drinking water (WHO, 2004). The standard for total chloride is $250 \mathrm{mg} / \mathrm{L}$. These imply that this water can be used for drinking and domestic purpose (Tables 1 and 3).

\section{Fluoride and Magnesium}

The total fluoride of the water sample varied significantly $(p>0.05)$. The values obtained varied from 0.2 to 0.3 , which is lesser than the standard for total fluoride for drinking water (Tables 1, 2 and 3). The standard for total fluoride for drinking water and domestic use is $1.5 \mathrm{mg} / \mathrm{L}$. These results corresponded with that of Ogunfowokan et al. (2005). Magnesium also test result also varied significantly $(p>0.05)$. The values obtained ranged from 152 to 157 which is higher than that of the WHO standard for drinking water (Table 3). The allowable value for magnesium concentration is 0.20 (WHO, 2004).

\section{Conclusion}

The study revealed that there was an adverse impact on the physiochemical parameter on the steam by discharge 
of sewages and industrial waste in to the stream and contaminates the stream. Waste from house hold may also be dump into the stream or carried in to the stream through drainage systems. This may pose a health risk to rural communities which rely on the water as a drinking source since the physiochemical parameter varied significantly from the standard set by the WHO and FEPA.

\section{Recommendation}

There is need for the intervention of appropriate regulatory agencies to ensure production of high quality water. Appropriate drainage system should constructed and channel away from water bodies that are used for domestic and industrial purpose. Proper publications and awareness to individuals and industries to avoid dumping of refuse or waste in water bodies meant for drinking and other domestic use. Good sewage drainage system should be constructed; and not channeled to water bodies. Proper recycling of domestic and industrial waste should be encouraged especially in the developing countries.

\section{CONFLICT OF INTEREST}

The authors declare that they have no conflict of interest.

\section{REFERENCES}

Adigun, B. A. (2005). Water quality management in Aquaculture and Freshwater zooplankton production for use in fish Hatcheries. New Bussa, Niger State, Nigeria, 12-13.

Aina, E. O. A., \& Adedipe, N. O. (1996). Water quality monitoring and environmental status in Nigeria. FEPA Monograph, 6, 239.

Calamari, D., Naeve, H., (1994). Review of pollution in the African Aquatic Environment. Committee for Inland Fisheries of Africa (CIFA), Technical paper No. 25, FAO, Rome, 118.

Chapman, D. (1996). Water quality assessments: A guide to the use of biota, sediments and water in environmental monitoring 2nd. Ed. UNESCO, World Health Organization, United Nations Environment Programme, London.

DFID (1999). A Simple Methodology for Water Quality Monitoring. Pearce, G. R., Chaudhry, M. R., \& Ghulum, S. (Eds.), Department for International Development, Wallingford. p. 100.

DWAF, (1995). South African water quality management series. Procedures to Assess effluent Discharge Impacts. WRC Report No. TT 64/94. Department of Water Affairs and Forestry and Water Research Commission, Pretoria.

DWAF, (1996b). South African Water Quality Guidelines, (Volume 2), Recreational Water Use (2nd Ed.). Department of DWAF; WRC, (1995).

DWAF, (1998). Quality of Domestic Water Supplies. Assessment Guide. 1 (2nd. Ed.) Department of Water Affairs and Forestry, Department of Health and Water Research Commission.

Dwivedi, B. K., \& Pandey, G. C. (2002). Physico-chemical factors and algal diversity of two ponds in Faizabad. India Poll. Res., 21(3), 361-370.

Fair, P. (1971). A Hypothesis concerning Silcia and fresh water plank tonic diatoms Limnol. Oceanogra, 16(1), 10-18.

Fatoki, O. S., Gogwana, P., \& Ogunfowokan, A. O. (2003). Pollution assessment in the Keiskamma River and in the impoundment downstream. Water SA, 29(2), 183-188.

Forenshell, G. (2001). Setting basin design. Western Regional Aquaculture Center, WRAC-106. USA: 6p.

Ghose, F., Basu, P. (1968). Eutrophication trends in the water quality of the Rhode River. J. Mar. Biol. Assoc., 54, 825-855.

Gray, A. V. (1989). Case study on water quality modelling of Dianchi lake, Yunnan province, southwest China. Water Sci. Technol., 40, 35-43.

Gupta, G. K., Shukle, R., (2006). Physiochemical and Bacteriological Quality in Various Sources of Drinking Water from Auriya District (UP) Industrial Area. Pollution Research, 23 (4), 205-209.

Jaji, M. O., Bamgbose, O., Odukoya, O. O., Arowlo, T. A. (2007). Water quality assessment of Ogun River, south west Nigeria. Environ. Monit. Assess, 133 (1-3), 447-482.

Katsuro, A., Yashiko, K., Yoshinnori, S., Takashi, T., \& Hayao, S. (2004). Heavy - metal Distribution in River Waters and sediment a "firefly village", Shikou, Japan: Application of multivariate Analysis. Analytical science, 20, 79-84.

Lloyd, B., Helmer, R., (1992). Surveillance of drinking water quality in rural area. Longman Scientific and Technical Publication. New York, Wiley. 34-56.

Morrison, G., Fatoki, O. S., Persson, L., Ekberg, A. (2001). Assessment of the impact of point source pollution from the Keiskammahoek Sewage Treatment Plant on the Keiskamma River-pH, electrical conductivity, oxygen demanding substance (COD) and nutrients. Water SA, 27(4), 475-480.

Ogunfowokan, A. O., Okoh, E. K., Adenuga, A. A., Asubiojo, O. I. (2005). Assessment of the impact of point source pollution from a University sewage treatment oxidation pond on the receiving stream-a preliminary study. J. App. Sci., 6(1), 36-43.

Okoh, A. I. (2007). Wastewater treatment plants as a source of microbial pathogens in the receiving watershed. Afr. J. Biotech. 6(25), 2932-2944.

Okoye, P. A. C., Enemuoh, R. E., \& Ogunjiofor, J. C.,(2002) Traces of heavy metals in Marine crabs. J. Chem. Soc. Nigeria, 27(1), 76-77.

Patil, D. B., \& Tijare, R. V. (2001). Investigation of Pollution Mystery of Suspected Carcinogen $\mathrm{Cr}(\mathrm{VI})$ and its Control. Journal Of Industrial Pollution Control, 17(1), 43-47.

Rao, P. V., (2005). Textbook of environmental engineering. Eastern Economy Ed.Prentice-Hall of India Private Limited, New Delhi, Chapter 3, 280.

Rast, W., \& Thornton, J. A. (1996). Trends in eutrophication research and control. Hydrological Processes, 10(2), 295313.

Sandoyin, C. (1991). Eutrophication trends in the water quality of the Rhode River. Journal Maritime Biological Association, 54(1), 825-855.

Schulz, K., \& Howe, B. (2003). Uncertainity and sensistivity analysis of water transport modeling in a layered siol profile using fuzzy set theory. J. Hydroinform., 1, 127-138.

Thompson, F. L., lida, T., \& Swings, J. (2004). Biodiversity of vibrios. Microbiology and Molecular Biology Reviews, 68(3), 
403-431.

UNEP (1993). Environmental data report (93/94). United Nation Environment Programme, Blackwell, Oxford, UK, Pp. 63-105.

Watson C; C Cichra (2006). Fertilization of fresh water fish ponds. Fact Sheet FA-17, Department of Fisheries and Aquatic Sciences, Florida Cooperative Extension Service, Institute of Food and Agricultural Sciences, University of Florida.

WHO, (1984). Guideline for Drinking Water Quality Recommendation. World Health Organization, Geneva, 1, 130.

WHO, (1989). Health guidelines for use of wastewater in agriculture and aquaculture. World Health Organization. Technical Report Series 778. Geneva, Switzerland.

WHO, (2002). Water and health in Europe: A joint report from the European Environment Agency and the WHO Regional Office for Europe. World Health Organization, WHO Regional Publications, European Series No. 93.
WHO, (2004). Rolling revision of the WHO guidelines for drinking-water quality, Draft for review and comments. Nitrates and Nitrites in drinking-water, World Health Organization. (WHO/SDE/WSH/04.08/56).

WRC (2000). National eutrophication monitoring programme. Water Research Commission. Implementation Manual. Draft Report, Water Research Commission, Pretoria.

Wurts, W. A. (2000): sustainance aquaculture in the twenty first century. Reviews in fisheries science 8 (2) 141-150. 